\title{
The assessment of a new protein source-Rapeseed
}

\author{
By G. R. FEnwick, ARC Food Research Institute, Colney Lane, Norwich \\ $N_{4}{ }_{7} U A$, Norfolk
}

Rapeseed, including both Brassica napus and Brassica campestris, is the fourth most important oilseed of commerce with a production and oil yield in $1980-8 \mathrm{I}$ of I I. 3 and $3.9 \mathrm{M}$ tonnes respectively. It is the only oilseed capable of commercial cultivation in Northern Europe and its growth is financially supported by the EEC. In Western Europe, over $2 \mathrm{M}$ tonnes of rapeseed is crushed annually, about a fifth of this within the UK. The production of rapeseed within the UK has increased dramatically over the last decade. In $1980-81$ the yield was 280000 tonnes (with an additional 140000 tonnes being imported). This upward trend is expected to continue and currently an estimated 160000 ha are under cultivation and a yield in excess of 400000 tonnes is expected for $1982-83$.

Rapeseed is grown primarily for its high oil content, which at $40 \%$ is approximately double that of soya bean. Originally, this oil was used for industrial lubrication but the successes of plant breeders in removing undesirable glycerides of erucic acid from the oil has led to its widespread use for edible purposes (Downey, 1976). Removal of the oil produces a high-protein meal which has been used widely as a feed for livestock and poultry. The potential of full-fat rapeseed and rapeseed protein concentrate as animal feed has also been examined, although much less extensively.

In this paper factors affecting the nutritional value of rapeseed meal will be reviewed, the usefulness of this and other rapeseed products as a source of protein for animals and poultry will be briefly discussed and problems currently limiting the use of rapeseed meal in the UK will be mentioned.

\section{Factors affecting the nutritional value of rapeseed meal}

Protein content and amino acid availability. Rapeseed meal may contain between $35^{\circ}$ and $400 \mathrm{~g}$ protein $/ \mathrm{kg}$ depending upon the cultivar and on the conditions of growing and processing. The amino acid composition of rapeseed meal compares well with that of soya-bean meal, the former being richer in sulphur amino acids but poorer in lysine (Clandinin, 1967). The nutritional value of rapeseed meal may be adversely affected by its method of preparation. Poor growth and feed conversion in poultry-fed rations containing expeller-processed rapeseed meal has been shown to result from lysine deficiency caused by the thermal destruction of this amino acid during processing (Clandinin, 1967). Other milder extraction processes, such as pre-press solvent and direct solvent extraction, are now generally used. If rapeseed meal is used to replace soya-bean meal on a weight for weight basis then lysine (and possibly methionine) supplementation will 
be needed. If, however, diets containing both rapeseed and soya-bean meals are balanced for essential amino acids and energy then no added benefit from such supplementation accrues.

Nwokolo et al. (1976) reported an average amino acid availability of $91 \cdot 9 \%$ for the sixteen amino acids in rapeseed meal (ranging from $78.4 \%$ for methionine to $95.8 \%$ for arginine). It has been suggested (Clandinin \& Robblee, 1978 ) that the protein in meal from the newer, low-glucosinolate cultivars of rapeseed (see p. 28I) is better utilized than that from conventional rapeseed. An improvement in amino acid availability is also claimed. The true amino acid availability values of meal from such improved cultivars range from 86 to $96 \%$ (Muztar et al. 1980). Recent studies (Campbell et al. 1981) have shown the meal from three cultivars of lowglucosinolate rapeseed to possess biological values (BV) of $90-91$, true digestibility values of $84-85$ and a net protein utilization (NPU) of 76 . The latter figure compared well with fish meal and was superior to most, if not all, commonly used protein supplements.

Whilst the amount and availability of amino acids is fundamental to the choice of an oilseed meal as a protein supplement for poultry and livestock rations, the presence of anti-nutritional or toxic factors determines the levels at which the product may be included. Such factors are considered below.

Fibre. The fibre content of rapeseed meal $(110-130 \mathrm{~g} / \mathrm{kg})$ is almost double that of soya-bean meal and results in a lowering of metabolizable energy and digestibility values and a decrease in the bioavailability of minerals. The metabolizable and digestible energy values of rapeseed meal and $45.8 \%$ soya-bean meal are shown in Table $I$ and it can be seen that the energy value of rapeseed meal is lowest for poultry. Various factors have been proposed to explain this finding, including the presence of fibre, goitrogens and tannins, the lack of available carbohydrate and the method employed for the determination of energy values (reviewed in Fenwick \& Curtis, r 980).

Considerable efforts have been directed toward the production of low-fibre/highenergy fractions from rapeseed suitable for inclusion in rations for monogastric animals and poultry. The most common approach involves dehulling. The low-hull fraction contains significantly lower levels of both fibre and tannins and possesses digestibility and metabolizable energy values similar to those of soya-bean meal

\section{Table I. Energy content $(M Y / / g g)$ of low-glucosinolate rapeseed meal and soya-bean meal}

\begin{tabular}{|c|c|c|}
\hline & $\begin{array}{l}\text { Rapeseed meal } \\
\quad \text { (as fed) }\end{array}$ & $\begin{array}{l}\text { Soya-bean meal } \\
\text { (as fed) }\end{array}$ \\
\hline Cattle isf. & 1185 & $13 \cdot 30$ \\
\hline Cattle NE & 1005 & 10.91 \\
\hline Growing chicken $\mathrm{YE}$ & 795 & 9.41 \\
\hline Adult chicken .IE & 8.37 & 941 \\
\hline Swine $D E$ & $12 \cdot 14$ & 1381 \\
\hline Swine $\| \mathrm{E}$ & I I 30 & 1183 \\
\hline
\end{tabular}


(Clandinin \& Robblee, 198I). A hull-rich fraction suitable for feeding to ruminants is also produced. In France the latter has been used as a feed for rabbits (Lebas et al. $198 \mathrm{r})$.

The inclusion of meal from a recently developed low-fibre rapeseed cultivar (Candle) in animal rations has not always shown the advantages expected from a product containing $90 \mathrm{~g}$ fibre/kg (Campbell et al. 1981). It seems probable, however, that commercially produced samples of Candle meal contain variable levels of fibre, in some instances being little different from the usual high-fibre rapeseed meals (Clandinin \& Robblee, I98r).

Availability of minerals. Mineral analysis alone would seem to indicate that rapeseed meal is generally a richer source of minerals than soya-bean meal. However, the presence of fibre and phytate (approximately $20 \mathrm{~g}$ phytate $/ \mathrm{kg}$ ) in rapeseed meal reduces the availability of these minerals (Nwokolo \& Bragg, 1977). Nwokolo \& Bragg (1980) have recently reported the average bioavailabilities of six important minerals in rapeseed meal (Table 2). Zinc was found to be particularly badly affected, with certain samples of rapeseed meal possessing an availability of as low as $23 \%$ for this element. Reduced availability of zinc is considered to be most damaging in rations containing rapeseed protein concentrate (see p. 286).

Tannins. Rapeseed meal contains approximately $20-30 \mathrm{~g}$ tannins $/ \mathrm{kg}$. Condensed tannins are found mainly in the seed coat and their removal by dehulling has been offered as an explanation for the increased nitrogen utilization of dehulled rapeseed meal by the pig (Vermorel \& Baudet, 1978). Soluble tannins are concentrated in the endosperm rather than the pericarp and may be removed by further extraction alone. The presence of such soluble tannins in rapeseed meal is now known to depress trimethylamine oxidation in the fowl (Fenwick et al. I98I) and produce egg taint.

Sinapine. Although the content of choline in rapeseed meal is nearly three times that of soya-bean meal, most of this occurs as sinapine, the ester of 4-hydroxy-3,5dimethoxycinnamic acid. The presence of relatively large amounts ( $10-20 \mathrm{~g} / \mathrm{kg}$ ) of sinapine in rapeseed meal contributes to the palatability problems which occur when large amounts of the latter are included in poultry rations (Fenwick \& Curtis, 1980). More importantly, the compound is the major source of trimethylamine, the chemical compound responsible for egg taint (Hobson-Frohock et al. 1977). Whilst methods have been proposed for the decomposition of sinapine in rapeseed meal

Table 2. Bioavailability of minerals in rapeseed meal and soya-bean meal

\begin{tabular}{lcc} 
Mineral & \multicolumn{2}{c}{ Average bioavailability $(\%)$} \\
\cline { 2 - 3 } Rapeseed meal & Soya-bean meal \\
Phosphorus & 75 & 89 \\
Calcium & 68 & 86 \\
Magnesium & 62 & 78 \\
Zinc & 44 & 67 \\
Copper & 74 & $5 \mathrm{I}$ \\
Manganese & 54 & 76
\end{tabular}


(Fenwick et al. 1979; Goh et al. 1979) the economic advantage of such processes remain unclear. No low-sinapine rapeseed cultivar has yet been identified (Fenwick \& Curtis, 1980).

Glucosinolates. The presence of glucosinolates in rapeseed meal represents the single most important factor limiting its potential as a protein supplement (Hill, I979; Clandinin \& Robblee, I98I; Thomke, I98I). Consequently, the commercial introduction of cultivars with much reduced (termed 'low' or 'zero') levels of these undesirable glycosides has lead to the expansion in the use of rapeseed meal which has been evident in the last decade.

Glucosinolates are present in all cruciferous seeds and plants. Under the influence of an enzyme, myrosinase, which is also present in these species, glucosinolates are broken down to a range of products (Fig. I). It is the varying properties of these breakdown products rather than those of the glucosinolates themselves, which are responsible for many of the deleterious effects associated with the feeding of rapeseed products (Fenwick \& Curtis, 1980). Some of these products are goitrogenic, others are potentially hepatotoxic whilst the majority are volatile and strongly pungent, being responsible for the 'bite' of mustard, radish and horseradish. It should be noted that these compounds may also be formed in brassica vegetables and so their properties are also relevant to human nutrition (Fenwick et al. 1982). Characteristic symptoms of the ingestion of large amounts of glucosinolates include reduced feed intake and performance, enlarged thyroid gland and reduced levels of circulating thyroid hormones. The rapeseed grown in Europe contains higher levels of glucosinolates $(40-80 \mathrm{~g} / \mathrm{kg}$ meal) than that grown in Canada ( $30-50 \mathrm{~g} / \mathrm{kg}$ meal) and is generally more goitrogenic. The breakdown of such large amounts of glucosinolates in rapeseed meal results in considerable palatability problems. Even if rapeseed meal is heat-treated during processing to inactivate the myrosinase, it is possible that glucosinolates may be broken down in vivo because of glucosinolate-degrading bacteria present in the intestinal tract.

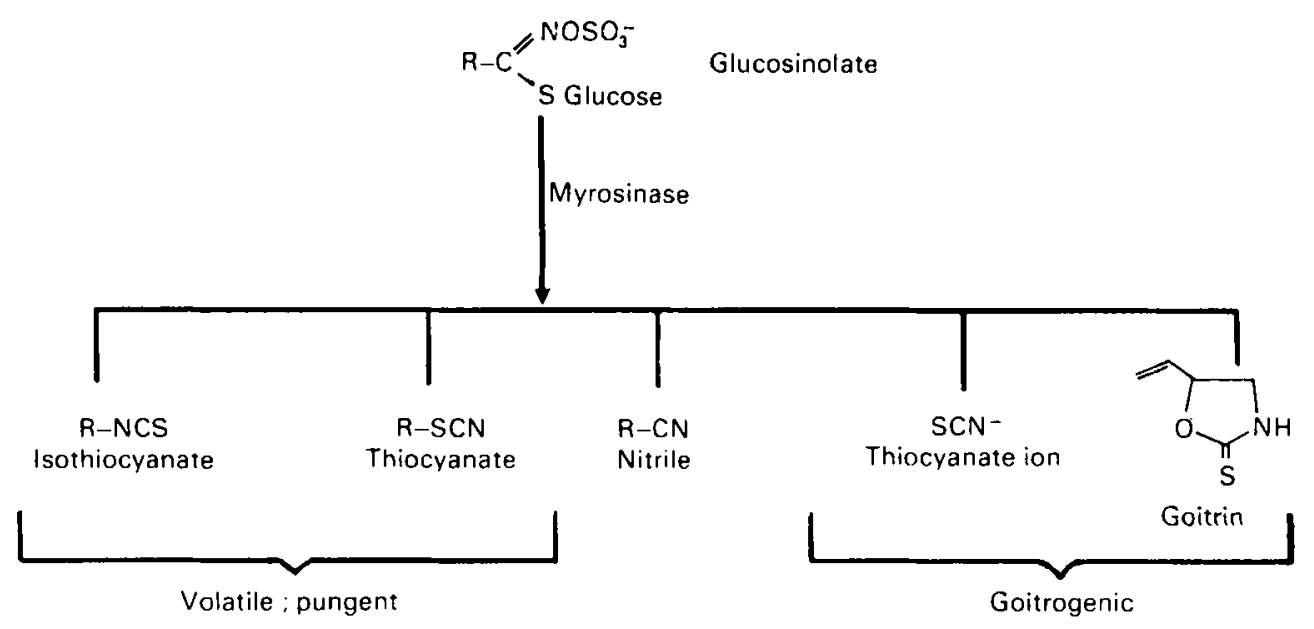

Fig. I. The breakdown of glucosinolates in rapeseed meal 
Numerous methods have been described for the reduction or removal ('detoxification') of glucosinolates from rapeseed meal (Maheshwari et al. I98I). Of much greater significance, however, has been the commercial introduction of low-glucosinolate rapeseed cultivars, the meal from which contains approximately $5^{-10} \mathrm{~g}$ glucosinolates/kg (Downey, 1976). Over $80 \%$ of the rapeseed currently grown in Canada contains low levels of glucosinolates and the term 'Canola' has been introduced to emphasize the advantages of such seed and its derived oil and meal over the earlier type. Reduction in the glucosinolate content may result in an increase in protein content (Clandinin \& Robblee, 1981).

The yields of winter-grown, low-glucosinolate rapeseed cannot yet compare with those of conventional, high-glucosinolate rapeseed. For this reason and because financial subsidies are not paid to growers or crushers to use the improved seed, the crop grown in the UK is almost entirely of the high-glucosinolate type, although some low-glucosinolate seed is imported for crushing. The introduction of improved cultivars is likely to occur within the next 2-4 years. However, unless the processing of these different types of rapeseed is kept separate during the 'change-over' period the nutritional and economic advantages of feeding lowglucosinolate rapeseed meal will not be fully realized.

\section{The use of rapeseed meal in livestock and poultry rations}

Ruminants. This subject has been reviewed recently by Thomke (198I). The maximum levels of inclusion of Canadian high- and low-glucosinolate rapeseed meal in rations for calves, beef and dairy cattle (as recommended by the Canola Council of Canada) are shown in Table 3 . The improved palatability of rations containing low-glucosinolate meal is of prime importance in maintaining their acceptability for fast-growing young animals and lactating cows. Efforts to overcome the problems of palatability encountered when high-glucosinolate

Table 3. Levels $(\mathrm{g} / \mathrm{kg})$ of inclusion of Canadian rapeseed meal in animal and poultry rations as recommended by the Canola Council of Canada

$\begin{array}{lcc}\text { Calves } & \begin{array}{c}\text { High-glucosinolate } \\ \text { rapeseed meal }\end{array} & \begin{array}{c}\text { Low-glucosinolate } \\ \text { rapeseed meal }\end{array} \\ \text { Dairy cattle } & 200 & 200 \\ \text { Beef cattle } & 100 & 20^{\circ} \\ \text { Starting pigs } & 100 & 200^{\circ} \\ \text { Growing pigs } & 50 & 120 \\ \text { Fattening pigs } & 50 & 120 \\ \text { Breeding pigs } & 50 & \vdots \\ \text { Starting poultry } & 30 & 120 \\ \text { Growing poultry } & 150 & 200 \\ \text { Laying and breeding chickens } & 150 & 200 \\ \text { Laying and breeding turkeys } & 50 & 100 \\ & 100 & 150 \\ & & \end{array}$


rapeseed meal is fed, for example, by adding molasses or flavouring agents, have been only marginally successful (Ingalls \& Sharma, 1975). The inclusion of highglucosinolate rapeseed meal as $15-20 \%$ of the concentrate for dairy cattle has an adverse effect on milk composition and decreases milk production. Whilst traces of glucosinolate breakdown products have been detected in the milk of cattle fed rapeseed meal (Papas et al. 1979; Laarveld et al. 1981) these are well within the levels regarded as safe for human consumption, bearing in mind the likely intake of such compounds via brassica vegetables (Mullin \& Sahasrabudhe, 1978). However, the potential hazard from such compounds would suggest that their levels in milk should be monitored routinely, especially when cattle are fed high-glucosinolate forages or rapeseed meals. Milk iodine-levels are reduced following the feeding of rapeseed meal but this can be alleviated by iodine supplementation (Thomke, 198I). Van Etten et al. (1977) were unable to detect any glucosinolates or breakdown products in the tissue of beef cattle fed meal from Crambe abyssinica, a product resembling rapeseed meal.

Whilst meal from low-glucosinolate rapeseed was more digestible to calves than that from coventional rapeseed (Shingoethe et al. 1974), recent studies have indicated that further improvement may be gained with the use of low-fibre rapeseed meal (cv. Candle), which of course also contains low levels of glucosinolates (Bush et al. 1978; Sharma et al. 1980).

Information about the effects of feeding UK-produced rapeseed meal is sparse. It is estimated that the product is used in cattle concentrates at inclusion rates of up to $10 \%$. This is in agreement with work from Sweden in which European-type high-glucosinolate rapeseed meal was fed at that rate for long periods without adverse effects on milk production and composition (Lindell, 1976). Any increase in inclusion rates much above this figure would require a clear demonstration that palatability problems had been overcome.

Non-ruminants: pigs. The feeding of high-glucosinolate rapeseed meals at levels greater than $60 \mathrm{~g} / \mathrm{kg}$ diet to gestating and lactating sows and gilts led to reduced litter sizes and lowered conception rates. Such effects were considered to be a consequence of glucosinolate decomposition products, although apparentiy not goitrogens (Marangos \& Hill, I977). Considerable advantages have generally been found in the use of low-glucosinolate rapeseed meals. For example, Flipot \& Dufour ( 1977 ) found that inclusion at $100 \mathrm{~g} / \mathrm{kg}$ of ration for gestating and lactating gilts caused no significant detrimental effects on reproductive performance or on subsequent performance of their litters. The levels for breeding and other classes of pigs, recommended as a result of Canadian experiences, are shown in Table 3 .

The available information suggests that at least half of the supplementary protein in the rations of starting and growing pigs can be met by low-glucosinolate rapeseed meal. For finishing pigs all of the supplementary protein can be supplied from this source. Starting pigs, however, are particularly susceptible to rapeseed meal; performance is significantly impaired even if low-glucosinolate meal provides all of the supplementary protein (McKinnon \& Bowland, 1979). No improvement was noted when low-fibre rapeseed meal provided all of the supplementary protein 
(Kennelly et al. 1978). For restricted-fed pigs, roo- $150 \mathrm{~g}$ low-glucosinolate rapeseed $\mathrm{meal} / \mathrm{kg}$ appears satisfactory but palatability problems are revealed with ad lib. systems. Claims for the improved palatability of low-glucosinolate rapeseed meal are not supported by Singam \& Lawrence (1979), who suggested that the poorer initial acceptability of this product (relative to soya-bean meal) to growing pigs might be due to tannins. More recent work by this group has also implicated an inferior apparent amino acid availability for the low-glucosinolate rapeseed meal. This study also suggested a possible interaction between dietary copper and rapeseed meal (Rowan $\&$ Lawrence, 1982). Since, with the exception of very young piglets, the restricted-feeding system is now generally employed in the UK, palatability problems may be expected to be less important than in, for example, Canada where feeding is usually $a d l i b$.

Information on high-glucosinolate rapeseed meal, typical of that produced in the UK, is limited. Rowan \& Lawrence (I982) found a high refusal rate when such rapeseed meal was fed at $29.5 \%$, but not at $17.5 \%$, of rations for $25-30 \mathrm{~kg}$ pigs. The observed inferiority of this product relative to meal from low-glucosinolate cultivars was considered to be due in part to an inferior apparent amino acid availability.

Marangos et al. (1976) fed meal from a high-glucosinolate $B$. napus cultivar at the $10 \%$ level to growing and finishing pigs and found no adverse effects on growth or carcass quality. Lee et al. (1980) have recently demonstrated that the low palatability of meal from UK-grown rapeseed was due to its glucosinolate content, rather than to its tannin or sinapine content. Such palatability problems are not removed by the addition of flavouring substances (Hill \& Lee, I980). It is likely that the level of inclusion of home-produced rapeseed meal in commercial pig rations in the UK is very low, probably not exceeding $30 \mathrm{~g} / \mathrm{kg}$.

Non-ruminants: Poultry. The use of rapeseed meals in poultry rations has been widely studied and reviewed (Fenwick \& Curtis, 1980; Clandinin \& Robblee, 1981). Maximum recommended levels of Canadian-type rapeseed meal for poultry rations are shown in Table 3. In addition, the advantages of using lowglucosinolate meal have been stated by Hill (1979). The maximum inclusion levels of UK-produced rapeseed meal for chicken, turkey and duck rations have been suggested to be $50 \mathrm{~g} / \mathrm{kg}$ (Anon, 1981) with the exception of layer and breeder rations where none at all should be added. The apparent inconsistency between the latter recommendation and that listed in Table 3 serves to illustrate the dangers inherent in extrapolating data obtained from feeding trials in one country to the situation pertaining in another. Not only does the nature and the glucosinolate content of the meal vary, but there may also be differences in the genetic basis of the livestock.

When rapeseed meal is included in rations for laying hens in the UK, a fishy taint occurs in many of the eggs. No such problems have been reported in commercial flocks in Canada. Whereas in Canada only white eggs are produced, production in the UK is almost entirely $(>90 \%)$ of the brown egg. It is now known that the taint occurs only in brown-egg-laying strains. Originally the problem was 
considered to be limited to the UK, but two factors have contributed towards making it of more general significance. Firstly, meal from low-glucosinolate rapeseed also causes taint in eggs laid by susceptible hens and secondly, over recent years there has been a swing towards brown egg production in Europe and other parts of the world. The problem was first reported in the UK in 1970-7I and rapeseed meal has been kept out of layer rations ever since.

The chemical and biochemical factors underlying the problem have now been largely elucidated (Fenwick \& Curtis, 1980 ). The taint is due to trimethylamine (at levels in excess of $0.8 \mathrm{ppm}$ ) which originates mainly from sinapine. Only certain birds are affected within brown-egg-laying strains because of a genetically controlled reduction in their capacity to oxidize, and excrete, trimethylamine in the normal way. This reduced ability is further diminished by the action of rapeseed meal tannins (Fenwick et al. 198I) and goitrogens (Pearson et al. 1979) in inhibiting hepatic trimethylamine oxidase.

Chemical treatment of rapeseed meal to reduce its tainting potential has been described (Fenwick et al. 1979) but would seem to be uneconomical. Plant breeding also seems unlikely to provide a solution since the complexity of the taint

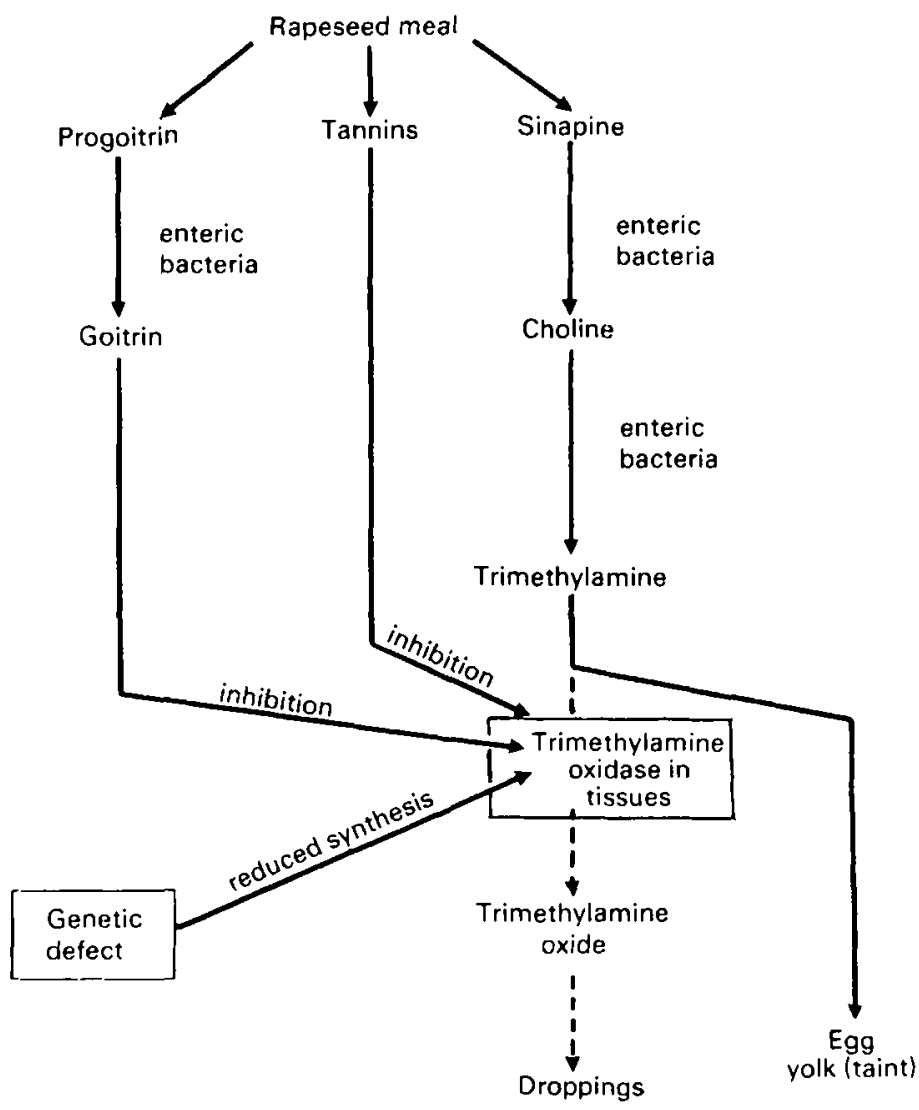

Fig. 2. The production of egg taint by rapeseed meal. 
production (Fig. 2) is such that soluble tannins, sinapine and glucosinolates would all need to be removed. The most likely solution at the present time would seem to be the removal of the genetic ('tainting') defect from commercial flocks by selective breeding.

An additional problem which has limited the use of rapeseed meal in layer and breeder rations is that of damage to the liver, culminating in massive liver haemorrhage and death. The condition is associated with hepatocyte degeneration, abnormalities in the biliary system and the leakage of cellular enzymes into the plasma (Butler et al. 1982). Whilst there is evidence to suggest that the feeding of diets containing low-glucosinolate rapeseed meal produces less severe haemorrhage (Campbell, 1979; Ibrahim \& Hill, 1980) it is as yet impossible to unambiguously relate the degenerate changes to any individual chemical compounds, or fractions, in rapeseed meal. Rational methods for preventing the liver damage cannot be devised until more information has been obtained on its cause and pathogenesis and work is being continued to those ends.

\section{Other rapeseed products}

Full-fat rapeseed. Full-fat rapeseed is not considered ordinarily as a feed for animals and poultry because of the high economic return on removing the oil. At certain times, it may, however, be economically viable to include the seed in such rations. The potential of full-fat rapeseed for poultry and cattle has been reviewed elsewhere (Fenwick \& Curtis, 1980; Thomke, 1981). Full-fat rapeseed may be protected from rumen fermentation by formaldehyde treatment. However, with the exception of the high producing dairy cow it is unlikely that the use of such protected lipids will be generally economic.

Castell \& Mallard (1974) found that full-fat high-glucosinolate rapeseed was not a satisfactory feed for pigs. Subsequently, Castell (r977) showed that up to I $50 \mathrm{~g}$ low-glucosinolate rapeseed $/ \mathrm{kg}$ could be included in grower/finisher diets without any adverse effects. Live performance and carcass measurements were unaffected when up to $15 \circ \mathrm{g}$ low-fibre Candle rapeseed/kg was included in grower/finisher pig rations. Increased levels of unsaturated fatty acids were found in the back-fat (Castell \& Falk, 1980).

The high oil content of the seed may cause problems during the formulation of rations and, whilst experimentation has not always indicated the need for heat treatment of the seed, it is suggested that this be carried out as a precautionary measure (Clandinin \& Robblee, I98I).

Rapeseed protein concentrate. The problems associated with feeding rapeseed meal, described above, have contributed to the examination and evaluation of rapeseed protein concentrate from the food safety, nutritional and acceptability standpoints. Rapeseed protein concentrate may contain $(\mathrm{g} / \mathrm{kg}) 600-700$ protein, $50-80$ fibre and $70-100$ ash. Protein efficiency ratios (PER) are as good as, or better than casein (McDonald et al. 1978; Jones, 1979). McDonald et al. (1978) have reported a $\mathrm{BV}$ of 89.9 (soya bean 65 ), NPU of 89.4 (soya bean 60.3 ) and a true 
digestibility of $99.5 \%$ (soya bean $92.8 \%$ ). The high nutritional quality of rapeseed protein concentrate was apparent when added (33\% of the protein) to a ground meat mixture. Olson et al. (1978) have shown that a blend of rapeseed protein concentrate with field pea was similar to the concentrate alone but the protein digestibility was much higher in mixtures with wheat or meat.

Sub-acute toxicity evaluations on rapeseed protein concentrate have been carried out on the beagle dog and rat (Loew et al. 1976). Rapeseed protein concentrates containing 0.90 and $0.03 \mathrm{mg}$ total glucosinolates/g were incorporated into semi-synthetic diets at inclusion rates of 20 and $40 \%$. Rats fed the higher level showed decreased serum thyroxine. Whilst thyroid iodine uptake, thyroid weight and thyroid histology were unaffected, both concentrate samples produced slight anti-thyroid activity.

Toxic effects of anorexia, wasting, apathy (all subsequent to the eighteenth day of pregnancy), bleeding from the eye and nose and high foetal mortality were noted in pregnant rats by Eklund (1973). These findings were later confirmed (with the exception of the bleeding) by McLoughlin et al. (1975). It is now widely accepted that these symptoms are a result of zinc deficiency brought about by the high phytate content $(5-8 \%)$ in the protein concentrate (McLoughlin et al. 1975). Supplementation of the diet with zinc relieved the above symptoms in the pregnant rat (Shah et al. 1979) and also increased the PER of the concentrate (McLoughlin et al. 1977). Recently, Shah, Benns et al. (198I) and Shah, Nera et al. (198I) have subjected rapeseed protein concentrates produced in Sweden and Canada, and supplemented with zinc ( $150 \mathrm{mg} / \mathrm{kg}$ ), to a short-term preclinical trial in weanling rats. No adverse effects on growth, iodine metabolism, blood chemistry or tissue mineral levels were noted even when the concentrate provided all the dietary protein. The absence of any significant effect on thyroid size confirmed the effectiveness of the processing conditions in reducing anti-thyroid compounds to a negligible level. The authors (Shah, Benns et al. 198I) have speculated that higher levels of zinc supplementation may adversely effect manganese and iron metabolism.

Rapeseed protein concentrate has not been approved for food use by any western nation and its immediate future may well be in the formulation of milk replacements for young animals and of pet foods. In the long-term it is conceivable that protein fractions from rapeseed may be used as supplements and extenders in meat and bakery products. In the event the major problem to be overcome may well be the 'reputation' of rapeseed and its products.

\section{Conclusions}

Rapeseed is grown primarily for its oil content. Removal of the oil provides a protein-rich meal which can be fed in relatively large amounts to ruminants. The use of such meal to feed ruminants is limited by the presence of fibre and glucosinolates. The content of the former may be reduced by dehulling and leads to a product possessing greatly increased digestibility. Palatability problems 
encountered when rapeseed meal is fed are primarily due to its high glucosinolate content and a significant advantage accrues from the use of meal from newer, lowglucosinolate cultivars.

Rapeseed produced in the UK is of the high-glucosinolate type and the meal is used mainly in cattle rations. The introduction of low-glucosinolate rapeseed into the UK will allow much greater amounts to be included in pig and cattle and some poultry rations. This may serve as a stimulus for further expansion of the crop in this country. Solutions to the problems of liver haemorrhage and egg taint are, however, needed before rapeseed can be included in rations for layer and breeder poultry.

\section{REFERENCES}

Anon (1981). Poult. Wld, ig Nov., 21.

Bush, R. S., Nicholson, J. W. G., McIntyre, T. M. \& McQueen, R. E. (1978). Can. F. Anim. Sci. $58,3^{69}$.

Butler, E. J., Pearson, A. W. \& Fenwick, G. R. (ıg82). J. Sci. Fd Agric. (In the Press.)

Campbell, L. D. (1 979). Br. Poult. Sci. 20, 239.

Campbell, L. D., Eggum, B. O. \& Jacobsen, I. (1981). Nutr. Rep. Int. 24, 79 I.

Castell, A. G. (1977). Can. J. Anim. Sci. 57, 111 .

Castell, A. G. \& Falk, L. (1080). Can. J. Anim. Sci. 60, 795.

Castell, A. G. \& Mallard, T. M. (1974). Can. J. Anim. Sci. 54, 443.

Clandinin, D. R. ( 1967 ). Poult. Sci. 46, 1596.

Clandinin, D. R. \& Robblee, A. R. (1978). Proc. 5th Int. Rapeseed Conf., Malmo, Sweden. Vol. II p. 204.

Clandinin, D. R. \& Robblee, A. R. (1981). F. Amer. Oil. Chem. Soc. 58, 682.

Downey, R. K. (1976). Chem. Ind. 401 .

Eklund, A. (1 973). Nutr. Rep. Int. 7,647.

Fenwick, G. R. \& Curtis, R. F. (1980). Anim. Fd Sci. Technol. 5, 255.

Fenwick, G. R., Heaney, R. K. \& Mullin, W. J. (1982). Crit. Rev. Fd Sci. Nutr. (In the Press.)

Fenwick, G. R., Hobson-Frohock, A., Land, D. G. \& Curtis, R. F. (1979). Br. Poult. Sci. $20,323$.

Fenwick, G. R., Pearson, A. W., Greenwood, N. M. \& Butler, E. J. (I981). Ann Fd Sci. Technol. 6,421 .

Flipot, P. \& Dufour, J. J. (1977). Can. J. Anim. Sci. 57, 567.

Goh, Y. K., Mueller, M. M., Clandinin, D. R. \& Robblee, A. R. (1979). Can. F. Anim. Sci. 59, 545 .

Hill, R. (1 979). Br. Vet. Y. 135, 3.

Hill, R. \& Lee, P. (1 980). Proc. Nutr. Soc. 39, 75 A.

Hobson-Frohock, A., Fenwick, G. R., Heaney, R. K., Land, D. G. \& Curtis, R. F. (1977). Br. Poult. Sci. 18, 539.

Ibrahim, I. K. \& Hill, R. (1980). Br. Poult. Sci. $21,423$.

Ingalls, J. R. \& Sharma, H. R. (1975). Can. J. Anim. Sci. 55, 521 .

Jones, J. D. (1979). J. Amer. Oil. Chem. Soc. 56, 7 I 6.

Kennclly, J. J., Aherne, F. X. \& Lewis, A. J. (1978). Can. J. Anim. Sci. 58, 743 .

Laarveld, B., Brockman, R. P. \& Christensen, D. A. (1981). Can. Y. Anim. Sri. 61, I3I.

Lebas, F., Seroux, M. \& Franck, Y. (1981). Ann Zootech. 30, 3 I 3 .

Lee, P., Pittam, S. \& Hill, R. (1980). Proc. Nutr. Soc. 39, $76 \mathrm{~A}$.

L,indell, S. L. (1976). Swed. F. Agric. Res. 6, 65.

Locw, F. W., Doige, C. E., Manns, D. G., Searey, G. P., Beu, J. M. \& Jones, J. D. (1976). Toxic Appl. Pharmac. 35, 257.

McDonald, B. E., Lieden, S.-A. \& Anjou, K. (1978). Nutr. Rep. Int. I8, 5 I.

McKinnon, P. J. \& Bowland, J. P. (r 979). Can. F. Anim. Sci. 59, 589.

McLoughlin, J. M., Beare-Rogers, J. L., Jones, J. D. \& Shah, B. G. (1977). Nutr. Rep. Int. 15, 33 I.

Mcloughlin, J. M., Jones, J. D., Shah, B. G. \& Beare-Rogers, J. L. (I975). Nutr. Rep. Int. I1, 327. 
Maheshwari, P. N., Stanley, D. W. \& Gray, J. I. (1981). F. Fd Protection 6, 459.

Marangos, A. G., Done, S. H. \& Hill, R. (1976). Br. Vet. F. 132, 380.

Marangos, A. G. \& Hill, R. (1977). Br. Vet. F. 133, 46.

Mullin, W. J. \& Sahasrabudhe, M. R. (1978). Nutr. Rep. Int. 18, 273.

Muztar, A. J., Slinger, S. J., Likuski, H. J. A. \& Darrell, H. G. (1980). Poult. Sci. 59, 605.

Nwokolo, E. \& Bragg, D. B. (1977). Can. F. Anim. Sci. 57, 475.

Nwokolo, E. \& Bragg, D. B. (1980). Poult. Sci. 59, 155.

Nwokolo, E., Bragg, D. B. \& Kitts, W. D. (1976). Poult. Sci. 55, 2300.

Olson, J. P., Sosulski, F. W. \& Christensen, D. A. (1978). F. Inst. Can. Sci. Technol. Anim. I, 93 .

Pearson, A. W., Butler, E. J. \& Fenwick, G. R. (1979). Vet. Rec. 104, 68.

Rowan, T. G. \& Lawrence, T. L. J. (1982). F. Sci. Fd Agric. (In the Press.)

Shah, B. G., Benns, G., Nera, E. A., Verdier, P. C., Beare-Rogers, J. L., Jones, J. D., Ohlson, R. \& Anjou, K. (198r). Qual. Plant Foods Hum. Nutr. 30, 235.

Shah, B. (.., Giroux, A., Belonje, B. \& Jones, J. D. (1979). Nutr. Metab. 23, 275.

Shah, B. G., Nera, E. A., Verdier, P. C., Beare-Rogers, J. L., Jones, J. D., Anjou, K. \& Ohlson, R. (1981). Qual. Plant Foods Hum. Nutr. 30, 223.

Sharma, H. R., Ingalls, J. R. \& Devlin, T. J. (1980). Can. F. Anim. Sci. 60, 915.

Shingoethe, D. J., Beardsley, G. L. \& Muller, L. D. (1974). J. Nutr. 104, $55^{8}$.

Singham, A. D. R. \& Lawrence, T. L. J. (1979). J. Sci. Fd Agric. 30, 2 r.

Thomke, S. (1981). F. Amer. Oil. Chem. Soc. 58, 805 .

Van Etten, C. H., Daxenbichler, M. E., Schroeder, L. H., Prince, L. \& Perry, T. W. (1977). Can. F. Anim. Sci. 57, 75 .

Vermorel, M. \& Baudet, J. J. (1978). Proc. 5th Int. Rapeseed Conf., Malmo, Sweden. Vol. II, p. 248. 